\title{
ELEMENTS OF NATURAL RADIOACTIVE DECAY SERIES IN IRANIAN DRINKING WATER AND CIGARETTES
}

\author{
Saeed MOHAMMADI \\ Payame Noor University, Physics Department, Mashad, Iran \\ Received in July 2009 \\ Accepted in March 2010
}

\begin{abstract}
The uranium $\left({ }^{238} \mathrm{U}\right)$ decay series provides the most important isotopes of elements radium $\left({ }^{226} \mathrm{Ra}\right)$, radon $\left({ }^{222} \mathrm{Rn}\right)$, and polonium $\left({ }^{210} \mathrm{Po}\right)$ with half-lives of about 1600 years, 3.8 days, and 140 days, respectively. Although the chemical structure of radium is very similar to calcium, the fact that it produces a radioactive gas (radon) complicates its handling in the laboratory and natural environment. In this study, we used the average concentrations of naturally occurring radionuclide ${ }^{226} \mathrm{Ra}$ in drinking water at different parts of Iran to estimate the annual effective dose. In the other part of the study, we measured the concentrations of ${ }^{210} \mathrm{Po}$ in Iranian cigarettes to estimate the internal intake of this radionuclide and its concentration in the lung tissues of smokers. The results indicate that the average concentration of ${ }^{226} \mathrm{Ra}$ in Iranian drinking water was below the $100 \mathrm{mBq} \mathrm{L}^{-1}$ recommended by the World Health Organization while the average concentration of ${ }^{210} \mathrm{Po}$ and ${ }^{210} \mathrm{~Pb}$ in Iranian cigarettes was relatively high in comparison with other cigarettes found on the market.
\end{abstract}

KEY WORDS: annual effective dose, polonium, radium, radon, uranium

Uranium is a naturally occurring primordial radionuclide; it was one of the elements created right after the Big Bang (1). It is the last naturally occurring element in the periodic table. The decay products of uranium pass over 10 elements, all with very different chemical properties. These elements are transported by groundwater, and their composition in the solution varies with the surrounding rock/soil minerals. Different elements migrate at different rates due to their different chemistries, dissolving in some areas and precipitating in others (1). In the ${ }^{238} \mathrm{U}$ decay series 8 alpha-particles are emitted from ${ }^{238} \mathrm{U}$ to ${ }^{206} \mathrm{~Pb}$. Alpha particles cause extensive ionisation in matter.

The uranium decay series provide the most important isotopes of elements radium, radon, and polonium, which are all radioactive and alpha emitters. Although the chemistry of radium is relatively simple, the fact that it produces a radioactive gas (radon) complicates its handling in the laboratory and natural environment. The decay of radon produces radioactive atoms of $\mathrm{At}, \mathrm{Po}, \mathrm{Bi}$, and $\mathrm{Pb}(1)$.

The radioactive noble gas ${ }^{222} \mathrm{Rn}$ is produced continuously from the decay of radium in the ground. It dissolves in groundwater, which often carries it in high concentrations and releases it to areas inhabited by humans. It diffuses readily through soil and into the atmosphere. Thus it is always present in the air and water at levels which are determined by local geology and meteorology. Its main target organ is the lung.

The relatively high activity concentrations of ${ }^{210} \mathrm{Po}$ in cigarettes increase the intake of this radionuclide and its concentration in the lung tissues adding to overall internal radiation dose among smokers (1).

The aim of our study was to estimate the annual effective dose based on average concentrations of naturally occurring radionuclide ${ }^{226} \mathrm{Ra}$ measured in 
drinking water in different parts of Iran. In the other part of research, we measured the concentrations of ${ }^{210} \mathrm{Po}$ in Iranian cigarettes to estimate the internal intake of this radionuclide and its possible concentration in the lung tissues of Iranian smokers.

\section{MATERIALS AND METHODS}

\section{${ }^{226} \mathrm{R}$ a determination}

In the winter and the summer between June 2003 and June 2004, we gathered samples of bottled drinking water $(\mathrm{N}=100)$ available in supermarkets from the northwest, northeast, west, central and south Iran (parts with highest population density), and determined ${ }^{226} \mathrm{Ra}$ activity in each. ${ }^{226} \mathrm{Ra}$ activity was measured using the radon emanation method (2) with a minimum detection limit of $2 \mathrm{mBq} \mathrm{L}^{-1}$.

Briefly, ${ }^{226} \mathrm{Ra}$ in drinking water sample was concentrated and separated by co-precipitation on barium sulphate (Merck, Germany). The precipitate was dissolved in ethylenediaminetetraacetic acid (EDTA) (Merck, Germany), placed in a sealed bubbler and stored for ingrowths of ${ }^{222} \mathrm{Rn}$. After ingrowths, the gas was purged into a scintillation cell. After 4 hours, when the short-lived ${ }^{222} \mathrm{Rn}$ daughters were in equilibrium with the parent, counted alpha-particle activity.

The annual effective dose of ${ }^{226} \mathrm{Ra}$ in drinking water was calculated according to the following formula:

$$
\mathrm{D}=\mathrm{C}_{\mathrm{Ra}} \times \mathrm{U}_{\mathrm{a}} \times \mathrm{D}_{\mathrm{f}}
$$

where $\mathrm{C}_{\mathrm{Ra}}$ is the concentration of ${ }^{226} \mathrm{Ra}\left(\mathrm{Bq} \mathrm{L} \mathrm{L}^{-1}\right), \mathrm{U}_{\mathrm{a}}$ is the annual adult intake of drinking water, which is about $40 \mathrm{~L}$, and $\mathrm{D}_{\mathrm{f}}$ is a conversion factor of radioactivity to the absorbed dose (or dose equivalent per $\mathrm{Bq}$ ) in $\mu \mathrm{Sv} \mathrm{Bq}^{-1}$. The United Nations Scientific Committee on the Effects of Ionizing Radiation (UNSCEAR) recommended $\mathrm{D}_{\mathrm{f}}$ for the intake of ${ }^{226} \mathrm{Ra}$ is $0.28 \mu \mathrm{Sv} \mathrm{Bq}^{-1}(3)$.

\section{${ }^{210} \mathrm{Po}$ and ${ }^{210} \mathrm{~Pb}$ determination}

For this experiment we used the method suggested by Saito (4). Several Iranian brands of cigarettes were selected from the market. We homogenised the content of three cigarette packs for each analysis and did it in triplicate. From each mixture, we allocated $15 \mathrm{~g}$ for ${ }^{210} \mathrm{~Pb}$ determination and another $15 \mathrm{~g}$ for ${ }^{210} \mathrm{Po}$ determination.
To each sample of $5 \mathrm{~g}$ of dry tobacco we added $1 \mathrm{~mL}$ of ${ }^{208}$ Po tracer (Merck, Germany). The sample was leached with $40 \mathrm{~mL}$ of concentrated nitric acid (Merck, Germany) heated at temperature not exceeding $70{ }^{\circ} \mathrm{C}$ in order to avoid losses of polonium by volatilisation. When the sample was close to the dryness, it was added another $30 \mathrm{~mL}$ of nitric acid. This procedure was repeated once more.

Then we added $10 \mathrm{~mL}$ of hydrogen peroxide (Merck, Germany) to destroy organic matter and $10 \mathrm{~mL}$ of nitric acid $\left(8 \mathrm{~mol} \mathrm{~L}^{-1}\right)$ under heating. To a nearly dry sample, we added another $10 \mathrm{~mL}$ of nitric acid $\left(8 \mathrm{~mol} \mathrm{~L}^{-1}\right)$. The sample was filtered directly into a separation funnel containing $5 \mathrm{~mL}$ of tributylphosphate (TBP; Merck, Germany). The mixture was then shaken for five minutes. After 10 minutes at rest, the polonium was found in the aqueous phase. The extraction was repeated twice with $10 \mathrm{~mL}$ of nitric acid $\left(8 \mathrm{~mol} \mathrm{~L}^{-1}\right)$. Then the aqueous phase was nearly dried by heating in order to eliminate nitric acid. Then we added $20 \mathrm{~mL}$ of concentrated hydrochloric acid (Merck, Germany) under heating. When the sample was almost dry we added another $20 \mathrm{~mL}$ of hydrochloric acid $\left(2 \mathrm{~mol} \mathrm{~L}^{-1}\right)$.

Iron was complexed by adding L-ascorbic acid (Merck, Germany) until the solution changed colour from yellow to colourless. The solution was then transferred to a plating cell, where ${ }^{208} \mathrm{Po}$ and ${ }^{210} \mathrm{Po}$ were spontaneously deposited onto a copper disc after $4 \mathrm{~h}$ of continuous agitation and heating at temperature below $70{ }^{\circ} \mathrm{C}$. The disc was then washed with deionised water and left to dry at room temperature. The alpha spectrum was obtained by counting in a surface barrier detector.

The counting efficiency was determined using an electrodeposited source of ${ }^{241} \mathrm{Am}$. The value obtained was $0.125 \pm 0.001$. The yield of the process ranged from $23 \%$ to $67 \%$ and the typical lower limit of detection of this method was $5 \times 10^{-5} \mathrm{mBq} \mathrm{g}^{-1}$ for 1,000 minutes of counting time.

\section{RESULTS AND DISCUSSION}

\section{Natural radioactivity from drinking water}

All waters in the biosphere have impurities. Successful monitoring, protection, and rational use of water from rivers and mountains requires complex and systematic studies of space-time distribution and migration of heavy elements such as ${ }^{226} \mathrm{Ra}$. Radium is a decay product of uranium and is generally in 
radioactive equilibrium with it on a global basis. It is much more soluble in water than uranium and therefore more readily leached by groundwater, making its way to drinking water and food. At high concentrations, this route of exposure becomes very important (1).

Table 1 shows ${ }^{226} \mathrm{Ra}$ average activity concentrations in drinking water in different parts of Iran. They do not exceed the $1,000 \mathrm{mBq} \mathrm{L}^{-1}$ recommended by the World Health Organization (5) for drinking water. The concentration of ${ }^{226} \mathrm{Ra}$ present in groundwaters used by people in the northwest and northeast Iran for medical purposes. Only in the southern part of Iran, ${ }^{226} \mathrm{Ra}$ was relatively high in comparison to other parts.

Table 1 Radioactivity of bottled water in different parts of $\operatorname{Iran}(N=100$ samples $)$

\begin{tabular}{lc}
\hline Location & $\begin{array}{c}\text { Average } \\
\text { concentration } / \mathbf{~} \mathbf{~} \mathbf{B q} \mathbf{~ L}^{-1}\end{array}$ \\
\hline North-West & $2.1 \pm 0.1$ \\
North-East & $2.6 \pm 0.2$ \\
Center & $2.3 \pm 0.2$ \\
West & $2.1 \pm 0.1$ \\
South & $6.2 \pm 0.7$ \\
\hline
\end{tabular}

Concentrations of ${ }^{226} \mathrm{Ra}$ vary greatly from location to location (1). Radium in the body becomes incorporated in bone, where it remains virtually indefinitely. The protection standard for radium was originally based on a maximum level in the body (maximum body burden).

Radium decays to ${ }^{222} \mathrm{Rn}$, which is an inert noble gas and the immediate daughter product of ${ }^{226} \mathrm{Ra}$. Natural radiation accounts for the majority of human exposure to radiation, and ${ }^{222} \mathrm{Rn}$ and its short-lived daughter products are the largest contributors to this radiation dose. Because of the radon health concern, several methods have been developed to monitor for radon and its daughters in air(6).

\section{Natural radioactivity from cigarette smoke}

The relatively high activity concentrations of ${ }^{210} \mathrm{Po}$ that are usually found in cigarettes increase internal intakes of this radionuclide and its concentration in the lung tissues of smokers. Polonium is a reactive, silvery-gray metal that dissolves in dilute acids. It is fairly volatile and about half will evaporate within two days if kept at $55^{\circ} \mathrm{C}$. A gram capsule of Polonium will reach $500{ }^{\circ} \mathrm{C}$ because of the intense alpha-radiation (7). That might contribute significantly to an increase in the internal radiation dose among smokers.
In addition to ${ }^{210} \mathrm{Po},{ }^{210} \mathrm{~Pb}$ with a half-life of 22 years is found in cigarettes as well. Since the burning temperature of a cigarette is around $700{ }^{\circ} \mathrm{C}$ and ${ }^{210} \mathrm{~Pb}$ is supposed to volatilise at temperature over $500{ }^{\circ} \mathrm{C}$, the percentage of ${ }^{210} \mathrm{~Pb}$ effectively inhaled will be an additional source of ${ }^{210} \mathrm{Po}$ for the lungs. The annual effective doses were calculated on the basis of ${ }^{210} \mathrm{Po}$ and ${ }^{210} \mathrm{~Pb}$ intake with the cigarette smoke.

Virtually all soils contain radium, a radioactive element that decays into ${ }^{210} \mathrm{~Pb}$ and ${ }^{210} \mathrm{Po}$. In addition, phosphate ore used to make fertilisers used on tobacco fields contains these isotopes in relatively high concentrations. While tobacco plants can absorb ${ }^{210} \mathrm{~Pb}$ and ${ }^{210} \mathrm{Po}$ through their roots, relatively little enters this way (1). When ${ }^{226} \mathrm{Ra}$, as a component of soil and fertiliser, decays, it gives rise to ${ }^{222} \mathrm{Rn}$, a gas that escapes into the air. This radon decays into its daughters, which have high electric charges that make them attach to dust particles. These dust particles stick to the tips or heads of the hairs of Tobacco leaves. Almost all the radioactivity of tobacco comes from this air deposition process. During processing of tobacco to cigarettes, this radioactivity is not removed from the tobacco leaves (1).

Equivalent doses resulting from a single disintegration of ${ }^{210} \mathrm{Po}$ (alpha-particle decay) are a thousand times greater than in the case of ${ }^{210} \mathrm{~Pb}$ decay (beta-particle decay) (8). The concentrations of ${ }^{210} \mathrm{Po}$ in cigarettes range between $3 \mathrm{~Bq} \mathrm{~kg}^{-1}$ and $37 \mathrm{~Bq} \mathrm{~kg}^{-1}$ and vary with cigarette brand, due to different varieties of tobacco and manufacturing procedures (9).

Our results show that the average activity concentration of ${ }^{210} \mathrm{Po}$ in Iranian cigarettes was $26 \mathrm{mBq}$ per cigarette. Assuming that $50 \%$ of ${ }^{210} \mathrm{Po}$ and ${ }^{210} \mathrm{~Pb}$ activity contained in a cigarette is inhaled during smoking, the annual activity concentration of ${ }^{210} \mathrm{Po}$ intake by smoking of one pack (20 cigarettes) per day during one year is $94.9 \mathrm{~Bq}[(26 \mathrm{mBq}$ per cigarette $)$ $\mathrm{x}(20$ cigarettes per day $)=520 \mathrm{mBq}$ per day $\mathrm{x} 50 \%=$ $260 \mathrm{mBq}$ per day x 365 days per year $=94900 \mathrm{mBq}$ per year $=94.9 \mathrm{~Bq}$ per year $]$.

By applying the dose conversion factor for adults of $4.3 \mu \mathrm{Sv} \mathrm{Bq}{ }^{-1}$ for ${ }^{210} \mathrm{Po}$ and $5.6 \mu \mathrm{Sv} \mathrm{Bq}{ }^{-1}$ for ${ }^{210} \mathrm{~Pb}$ (10), the average annual committed effective dose is $408 \mu \mathrm{Sv}\left(94.9 \mathrm{~Bq} \times 4.3 \mu \mathrm{Sv} \mathrm{Bq}{ }^{-1}\right)$ and $532 \mu \mathrm{Sv}$ $\left(94.9 \mathrm{~Bq}\right.$ x $\left.5.6 \mu \mathrm{Sv} \mathrm{Bq}^{-1}\right)$ or approximately $0.4 \mathrm{mSv}$ to $0.5 \mathrm{mSv}$ due to cigarettes smoking for ${ }^{210} \mathrm{Po}$ and ${ }^{210} \mathrm{~Pb}$, respectively.

Table 2 shows an activity comparison between Iranian cigarettes and those from other countries that are mostly found on the Iranian market and reported 
in literature $(11,12)$. As it can be seen, the average concentration of ${ }^{210} \mathrm{Po}$ in Iranian cigarette is relatively high in comparison to other cigarette brands.

Table 2 The average activity concentrations of ${ }^{210}$ Po in Iranian and foreign cigarettes $(9,10)$.

\begin{tabular}{lc}
\hline Country & $\begin{array}{c}\text { Average }{ }^{\mathbf{2 1 0}} \text { Po concentration / } \\
\mathbf{m B q} \text { per cigarette }\end{array}$ \\
\hline Iran & 26 \\
France & 23 \\
Brazil & 19 \\
Russia & 14 \\
Egypt & 14 \\
Turkey & 14 \\
Poland & 13 \\
\hline
\end{tabular}

\section{CONCLUSIONS}

${ }^{226} \mathrm{Ra}$ in bottled drinking available in supermarkets of Iran $\mathrm{mBq} \mathrm{L} \mathrm{mBq} \mathrm{Lwere} \mathrm{well} \mathrm{below} \mathrm{the} \mathrm{threshold}$ level of $100 \mathrm{mBq} \mathrm{L}^{-1}$ recommended by the WHO for drinking water. On the other hand, the average activity concentration of ${ }^{210} \mathrm{Po}$ in tested Iranian cigarettes ( $26 \mathrm{mBq}$ per cigarette), was relatively high in comparison with foreign cigarette brands found on the market, suggesting an increase in internal radiation dose and possible health risks for the exposed smokers from ${ }^{210} \mathrm{Po}$ and ${ }^{210} \mathrm{~Pb}$ contained in cigarette tobacco.

\section{REFERENCES}

1. Shapiro J. Radiation Protection: A Guide for Scientists, Regulators, and Physicians. $4^{\text {th }}$ ed. Cambridge (MA): Harvard University Press; 2002.

2. Kotrappa P, Stieff LR. Application of NIST ${ }^{222} \mathrm{Rn}$ emanation standards for calibrating ${ }^{222} \mathrm{Rn}$ monitors. Radiat Prot Dosim 1994;55:211-8.

3. United Nations Scientific Committee on the Effects of Atomic Radiation (UNSCEAR). UNSCEAR Report 2000, Vol. 1 [displayed 29 March 2010]. Available at http://www.unscear. org/unscear/en/publications/2000 1.html.

4. Saito RT. Determination of ${ }^{210} \mathrm{Po}$ and ${ }^{210} \mathrm{~Pb}$ in sea samples and aerosols [Determinação de ${ }^{210} \mathrm{Po}$ and ${ }^{210} \mathrm{~Pb}$ em amostras marinhas e aerossóis, in Portuguese]. [MA thesis]. Sao Paulo, Brazil: Institute of Energy and Nuclear Research; 1996.

5. World Health Organization (WHO). Radiological aspects. In: Guidelines for drinking water quality. $3^{\text {rd }}$ ed. 2004 [displayed 29 March 2010]. Available at http://www.who. int/water_sanitation_health/dwq/en/gdwq3_9.pdf.

6. Ziegelheim CJ, Büsigin A, Phillips CR. Development of a continuous monitor for ${ }^{226} \mathrm{Ra}$ in water. Health Phys 1982;42:317-27.

7. Emsley J. The Elements. $3^{\text {rd }}$ ed. Oxford: Oxford University Press; 2000

8. Parfenov YD. Polonium-210 in the environment and in the human organism. At Energy Rev 1974;12:75-143.

9. Skwarzec B, Struminska DI, Ulatowski J, Golebiowski M. Determination and distribution of ${ }^{210} \mathrm{Po}$ in tobacco plants from Poland. J Radioanal Nucl Chem 2001;250:319-22.

10. Khater AEM. Polonium-210 budget in cigarettes. J Environ Radioact 2004;71:33-41.

11. Peres AC, Hiromoto G. Evaluation of ${ }^{210} \mathrm{Po}$ and ${ }^{210} \mathrm{~Pb}$ in cigarette tobacco produced in Brazil. J Environ Radioact 2002;62:115-9

12. Colangelo $\mathrm{CH}$, Huguet MR, Palacios MA, Oliveira AA. Levels of ${ }^{210} \mathrm{Po}$ in some beverages and in tobacco. J Radioanal Nucl Chem 1992;166:195-202. 


\section{Sažetak}

\section{ELEMENTI NASTALI RASPADOM IZ PRIRODNIH RADIOAKTIVNIH NIZOVA U PITKOJ VODI I CIGARETAMA U IRANU}

Uranijev $\left({ }^{238} \mathrm{U}\right)$ radioaktivni niz obuhvaća najvažnije izotope radija $\left({ }^{226} \mathrm{Ra}\right)$, radona $\left({ }^{222} \mathrm{Rn}\right)$ i polonija $\left({ }^{210} \mathrm{Po}\right)$, a poluvijek raspada im je 1600 godina za prvi element, 3,8 dana za drugi te 140 dana za treći. Premda je radijeva kemijska struktura vrlo slična kalcijevoj, rukovanje njime u laboratoriju i prirodnome okolišu otežano je činjenicom da proizvodi radioaktivni plin radon.

S pomoću prosječnih koncentracija prirodnoga radionuklida ${ }^{226} \mathrm{Ra} u$ pitkoj vodi izračunali smo njegovu godišnju efektivnu dozu u različitim dijelovima Irana. U drugome smo istraživanju izmjerili koncentracije ${ }^{210} \mathrm{Po}$ u iranskim cigaretama i izračunali njegov unos i koncentracije u plućnome tkivu. Naši rezultati upućuju na to da je prosječna koncentracija ${ }^{226} \mathrm{Ra} u$ pitkoj vodi niža od $100 \mathrm{mBq} \mathrm{L} \mathrm{L}^{-1}$ koju preporučuje Svjetska zdravstvena organizacija, dok je prosječna koncentracija ${ }^{210} \mathrm{Po} \mathrm{i}{ }^{210} \mathrm{~Pb}$ u iranskim cigaretama relativno visoka u odnosu na druge cigarete dostupne na tržištu.

KLJUČNE RIJEČI: polonij, radon, radionuklidi, uranij

\section{CORRESPONDING AUTHOR:}

Saeed Mohammadi, PhD

Payame Noor University, Physics Department

P.O. Box 91735-433

71 Moallem Boulevard, Mashad, Iran

E-mail:mohammadi@pnu.ac.ir 